\title{
Business Model Analysis for Convene Based on POCD and PEST Framework
}

\author{
Angda Shen ${ }^{1, *,}$ a, $†$ Yanxin Wang ${ }^{2, *, b, \dagger}$, Shaojia Zhi ${ }^{3, *, c, \dagger}$ \\ ${ }^{1}$ Angda Shen, Department of Traffic, Tongji Zhejiang College, Zhejiang, China \\ ${ }^{2}$ Yanxin Wang, Cockrell School of Engineering, University of Texas at Austin, Austin, US \\ ${ }^{3}$ Shaojia Zhi, Vancouver School of Economy, University of British Columbia, Vancouver, Canada \\ *Corresponding author.Email: $5594306301 @ q q . c o m,{ }^{b}$ yanxinwang@utexas.edu, ${ }^{*}$ leah1999@student.ubc.ca \\ These authors contributed equally.
}

\begin{abstract}
The coworking industry in the US is currently experiencing strong growth because the companies are recovering from the Covid-19 impact. Research has shown that venture capital has a significant impact on economic growth through the financing of startups. We choose the company Convene to argue from the investor's view whether it is worth investing from the venture capital. Using the POCD framework and PEST analysis, we deduce there's a foreseeable opportunity for Convene to attract more customers and expand its business as more venture capital comes in. The results suggest that Convene is profitable during this period of high growth in the coworking industry. It also can be concluded that Convene is a good choice to invest in according to the elements of executive teams, interior factors, and the macroenvironment. This paper is the first attempt to analyse the external environment of the company Convene, and it is hoped that this paper will be a future reference for more venture capital investment in the coworking industry.
\end{abstract}

Keywords: Convene, coworking, venture capital, POCD framework, PEST analysis.

\section{INTRODUCTION}

With the development of technology and creation activities, venture capital (VC) emerges as a new investment way. It is an indispensable part of the investment. Most VC firms seek to provide business advice to startups to foster startup performance [1]. A start-up company is weak when the company is founded in little time. They don't have mature technology. They had to burn much money on research. However, as a start-up company, they have too little money to support their development of technology. Venture capital will invest money to plunk for a start-up company, and venture capital also uses a low price to get a partial stake in the company. They will receive a huge return if the start-up company becomes a successful company in the future. ByteDance was a start-up company in 2014. Sequoia capital china invests Bytedance, both of them get what they want. Sequoia capital china gives money to support the development of ByteDance. They have a huge return in a few years.

It is important to conduct $\mathrm{VC}$ and $\mathrm{PE}$ to startup enterprises. This paper establishes an analysis framework to evaluate the firms' investment valuation with a series of business models.

To effectively analyze an enterprise, several special techniques have been developed [2]. The POCD framework and PEST analysis are the perfect ways to show the strengths and weaknesses of the company. The POCD framework provided a systematic way to evaluate and analyze the challenges of managing a growing entrepreneurial venture [3] through four components: people, opportunity, context, and deal. PEST analysis is a powerful and widely used tool for understanding strategic risk. It identifies the changes and the effects of the external macro-environment on a firm's competitive position [4]. It consists of political, economic, social, and technological factors beyond the firm's control [5]. These external factors are essential to the investors because they can mitigate the possible impacts from the macroenvironment through a preemptive strategy. Opportunities are exploited in the wake of the process.

The main theme we researched was the decisionmaking of investment as a VC. It is about whether to invest in a company and how to evaluate the firms' valuation. In this paper, we used several information and 
models to investigate a company and evaluate it. The two main approaches employed were the POCD framework and the PEST model. By applying the POCD framework, PEST Model, and reviewing several company's information, we find the advantages and challenges of Convene. For instance, people will return to the office, and the demand for working space will increase. If Convene can seize this opportunity, the loss during the crisis will be compensated. In addition, the development of technology will help Convene to reduce costs for labor. For example, AI technology can replace some human workers. In contrast, there are some drawbacks and challenges. First, the policy of increasing tax and elevating minimum wage will be a huge burden for the development of Convene. Also, if competitors try to enter the high-end market, Convene may lose its advantages. After taking account of every factor, the conclusion is that VC should invest in Convene. The prospect of Convene is clear, and the environment is suitable for development.

The remainder of the paper is organized as follows: Section 2 give an introduction of the Convene and some important information; Section 3 employs the PEST model to analyze the environment and value of Convene, which includes Politics, Economy, Social and Technology; Section 4 uses POCD model to analyze the market and internal structure of Convene which includes People, Opportunity, Contexts, and Deal; Section 5 includes the investment advice when regarding previous model and information; Section 6 includes the conclusion.

\section{DESCRIPTION FOR THE CONVENE}

Due to the unique models and scenes of Convene, lots of investors pay attention to convene. We have a summary of the financial history of the convene in Table 1.

Table 1. Convene's the financial history

\begin{tabular}{lll}
\hline Transaction Name & Money Raised & Lead Investors \\
\hline $\begin{array}{l}\text { Series D - Convene } \\
\text { Series C - Convene }\end{array}$ & $\$ 152 \mathrm{M}$ & ArrowMark Partners \\
& $\$ 68 \mathrm{M}$ & ArrowMark Partners, Conversion \\
& & Ventures LLC \\
Series B - Convene & $\$ 20 \mathrm{M}$ & Brookfield Property Partners \\
Debt Financing - Convene & $\$ 15 \mathrm{M}$ & - \\
Series B - Convene & $\$ 15.5 \mathrm{M}$ & Conversion Ventures LLC \\
Series A - Convene & $\$ 10 \mathrm{M}$ & Boathouse Capital, Tamarix Capital \\
\hline
\end{tabular}

We could find six rounds of financial history in the sheet. They raise $\$ 280 \mathrm{M}$ money by the six rounds. Convene is invested by several lead investors who offer more opportunities and money to convene. The company has access to experience about technology, hospitality, and services from experienced investors.

The first round of Convene has two lead investors, Boathouse capital and Tamarix Capital. Boathouse Capital is a Philadelphia-based private equity firm with $\$ 350$ million of capital under management. They invest $\$ 5$ million to $\$ 40$ million of flexible capital in the form of debt and/or equity into high-growth middle-market companies, including SaaS/software, technologyenabled services, and healthcare IT/services companies, Boathouse Capital invest almost $\$ 10 \mathrm{M}$ dollar to Convene with Tamarix Capital.

Conversion ventures LLC is a venture capital company. Conversion Venture Capital (CVC) focuses on control and growth investments in quality mid-market businesses, which would benefit from a long-term investment perspective. It invests $\$ 10 \mathrm{M}$ dollar with some business partners in the first series B. Convene still lacks money after the first series B, so they choose to have a debt to get money.
Convene has its unique models and services in the coworking industry, it attracts Brookfield Property Partners to invest. Brookfield Property Partners is a big property company. They do invest in property and rent services. They invest \$20M dollar to Convene. ArrowMark Partners joined the investment in series $\mathrm{C}$ with Conversion Ventures LLC, which invested in the second time.

Conversion Ventures LLC is willing to have a second investment. It proves that convene can be successful. The total amount of money raised by Convene is $\$ 68 \mathrm{M}$ dollar.

ArrowMark Partners is an SEC-registered investment adviser based in Denver, Colorado. Their investment objective is clear: deliver consistent, asymmetric, noncorrelated, risk-adjusted returns by applying fundamental research across the capital structure. They supported convene with $\$ 152 \mathrm{M}$ money in series D.Definitely, as an investment advice company, they have lots of analysis and calculation, they think Convene is worth investing.

\section{PEST ANALYSIS}

Generally, the external environment of an enterprise is not controlled by itself. PEST (Politics, Economy, Social, Technology) is a macro-environment 
management method whereby an organization can assess the company's main external environmental factors from the four aspects [6]. Analyzing the external environment from a strategic point of view, grasping the current situation and changing trends, taking advantage of opportunities that are conducive to the development of the enterprise, and avoiding the threats which may bring a primary issue to the enterprise are the primary issues for the company to become more competitive in the market.

Several political factors have the potential to affect Convene's business. One of the most significant is the potential for local, state, or federal tax policy changes. President Biden currently wants to increase the corporate tax rate to ensure that corporations pay their fair share. According to Erica York of the Tax Foundation, the proposed increase would make the U.S. corporate tax rate the highest of all industrialized nations. If the rate increase goes through, Convene's net profit will likely decrease because its tax burden will increase. If state or local taxes increase, Convene's net profit will decrease even further. The government could also pass new laws restricting Convene's operations in some way. For example, if the number of COVID cases rises again, the government could prohibit business professionals from having hybrid meetings, which would cause Convene to lose some of its revenue.

One of the main economic factors that could affect Convene's business is pushing for a $\$ 15$ federal minimum wage in the United States. Those in favor of the increased state that it is necessary to help workers keep up with rising costs. President Biden has already issued an executive order to increase the minimum wage to $\$ 15$ per hour for federal contractors, indicating that his administration supports a national increase. If the minimum wage goes up, Convene may need to pay more for labor. The unemployment rate could also affect Convene's business. In May 2021, the U.S. unemployment rate dropped to $5.8 \%$. This is a vast improvement over the unemployment rate from April 2020, shortly after local governments started issuing shutdown orders to help combat the COVID-pandemic. In April 2020, the U.S. unemployment rate was $14.7 \%$ [7]. As the unemployment rate declines, Convene may find it more difficult to attract employees. The company may have to offer higher wages or better benefits to ensure it has the talent it needs to continue growing.

Many social factors have the potential to affect Convene, including the COVID-19 pandemic. Although many people have been vaccinated and states are starting to open up, there has been a shift in how many companies do business. More employees are working remotely, and businesses see the benefits of doing virtual meetings instead of in-person meetings. As a result, the demand for Convene's services is likely to increase. Consultants from McKinsey \& Company believe that many employers are likely to adopt a hybrid model, allowing people to work from home part of the time and an office the rest of the time. Convene can respond to this trend by making office space available in more cities. Expected population growth is another important social factor. The U.S. Census Bureau expects to add 79 million people to the U.S. population in the next 40 years. Companies may not want to rent additional space to accommodate so many new workers, increasing the demand for Convene's virtual and hybrid meeting services. The number of coworking spaces is also expected to increase to over 40,000 by 2024 .

Technological factors play a big role in the macroeconomic environment for Convene and its competitors. Artificial intelligence is likely to affect the industry significantly, as many companies are now embedding AI into their video conferencing software. Convene and other companies in this space may be able to use AI tools to reduce their labor costs. For example, some software packages have AI assistants available, eliminating the need for a human worker to take notes or track attendance. Another technological factor is the ability to share content during video meetings. The need to share content could drive up demand for virtual meetings.

Using the PEST model based on the above macroenvironmental analysis, an increase in corporate tax rate and minimum wage may lead to a higher operation cost. However, as the states open up and are recovering from Covid-19, we see opportunities of applying the virtual meeting method. From the investment perspective, we choose to remain neutral as the macro-environment was in precarious circumstances.

\section{POCD FRAMEWORK}

One important tool employed by analysts and VC to evaluate a new start-up company is the POCD framework which refers to research and analysis of four parts of a business: People, Opportunity, Contexts, and Deal.

In general, the part of People focuses on the entrepreneur's team, which includes the competence, skills of risk minimization, knowledge, and skills to create products and services in the innovation sector. To be short, people's attitudes, knowledge, contacts, goals, and values, which mix with the resource, can contribute centrally to success [8]. Opportunities include the entrepreneurial possibility in demand with the market and how business projects can provide steady income. The part of Contexts is about how leaders can generate revenue in various environments [9]. Such contexts mainly include economic, regulatory, and sociopolitical environments [8]. In the case of Convene, the part of people will focus on the leadership team. The opportunity part is about an industry where Convene is at and the concerns of competitors, especially Wework, which is 
regarded as a superpower in the industry. Contexts examine the environment and some externalities, in this case, mainly about the Covid-19 pandemic. In the part of the deal, the financial history is reviewed, and some data are presented and compared; at the same time, information and background of several investors are listed. The part of the deal is included in the previous sector, which analyzes the financing history of Convene.

For people, the most important and influential person is Ryan Simonetti, the Co-Founder, and CEO of Convene. Ryan was a graduate of Villanova University, and besides his role as leader of Convene, he was also a progressive venture investor. $\mathrm{He}$ was an innate entrepreneur who always thinks about big ideas as a founder and is willing to serve other start-ups as an advisor. Besides his educational background and inherent personality, his work experience facilitates his pace of starting a new company. Before starting Convene with his classmates Christopher, Ryan worked for a wellknown investment advising firm called Gramercy Capital Corp, and Ryan served as the vice president. In Gramercy, Ryan was responsible for reconstructing billions of dollars of the portfolio, and 600 million was specified for real state. Such experience endows Ryan plenty of knowledge of investment and real estate, which becomes his basis for starting Convene, which was related to the real estate industry. Before joining the Gramercy, Ryan worked as a real estate banking analyst in Lehman Brothers. To be short, Ryan's experience, leadership, and personality enhance the birth and progress of Convene.

For opportunity, the co-working industry is not newborn, and many competitors exist. For instance, Wework can be regarded as a super big company with a valuation of 9 billion dollars. Meanwhile, by comparison, Convene has a valuation of about 5 hundred million dollars. Besides Wework, there are many other companies in the same industry. The advantage of Convene is that it targets a high-end market, and it provides 5-stars hospitality and service, which almost no other companies compete with them. At the same time, Wework targets a mid-level market. In general, Convene's prospect will be excellent if Wework and other companies do not enter into the high-end market, but it is complicated to predict the strategy of others. In contrast, there are several drawbacks. Convene's location is few, and almost only in the metropolis in the US, it is difficult to access if consumers are not in New York, LA, Boston, or London. However, it may be a good sign of opportunity. Convene's business model is mature, successful and they can easily expand their business to Europe (only London for now), Asia... if they get more investment. In conclusion, the opportunity part is ambiguous since there are many competitors, but Convene can develop its landscape.
For the part of the context, the study is focused on the influences caused by the Covid-19 Pandemic. Convene survives during the crisis, and it is the achievements of people in Convene who propose fitting plans to get over. Yet the process is tough: Convene aims to reduce all controllable costs, including the hard decision to lay off and furlough $77 \%$ of the team members. In addition, Convene tried delaying or cancelling all large capital expenditures and growth investments to protect and preserve cash. Meanwhile, Convene worked closely with their landlord partners to modify our existing deals to temporarily reduce our monthly real estate expenses and buy time for our core meeting $\&$ events business to come back online. Economically, Convene partnered with shareholders and lenders to raise more capital and secure our balance sheet. Now, vaccines are employed, and people will return to work or school soon. The problem is how the team of Convene responds to the high demand for working space when people return to work. It is clear to see that the contexts give Convene a chance to thrive and develop its business. If Convene can seize this special opportunity, Convene will elevate to the next level, attract more investment, have a higher valuation, and occupy a bigger share of the industry.

In general, regarding the POCD framework, the decision is that VC should invest in Convene. The part of People is clear since the founder of Convene is trustworthy and capable. The opportunity is equivocal, but Convene still has the chance to compete with others and occupy a bigger share of the market. The part of contexts shows that Convene can survive during the crisis, and Convene has a chance to develop to a higher level after the pandemic.

\section{RECOMMENDATION}

Due to its specificity, Venture Capital may successfully finance companies in all stages of business, even those extremely specific and difficult [10].

Convene is a start-up company that is developing quickly. It has a huge market in the co-working industry. The models and services of Convene are different from other co-working industries. Convene has stable customers, they choose to offer services for the members that they have a cooperation with big companies, they have a nice facility to work and have a rest. Convene is a professional corporation which offers the members a good working experience in a comfortable environment with the best services, such as delicious food, a nice gym, service of five-star hotels.

\section{CONCLUSION}

This paper will research the feasibility of investing in Convene by using the PEST model, POCD framework, and research information. At the same time, VC's 
importance and the procedures of making investment decisions are also referred to.

According to the above analysis, as the country is being recovered from covid-19, we found a new growth opportunity for coworking spaces since businesses are opting more frequently towards coworking space solutions. Using PEST analysis and POCD framework, we concluded that with coworking as a highly profitable business model, the industry could expect further popularization of the virtual meeting model. Low unemployment rates and proven technology convey that the industry displays ideal status as a business hub that attracts venture capital.

In conclusion, as the country is being recovered from Covid-19, we found a new growth opportunity for coworking spaces since businesses are opting more frequently towards coworking space solutions. Using PEST analysis and POCD framework, we concluded that with coworking as a highly profitable business model, the industry could expect further popularization of the virtual meeting model. Low unemployment rates and proven technology convey that the industry displays ideal status as a business hub that attracts venture capital.

We still have some shortages in articles. The information is not easy to get. We don't have much data to support our opinions. We will take new plans for our research, forecast the revenue of the enterprise. It is significant to help us forecast an enterprise's future. We can have more accurate forecasting.

\section{REFERENCES}

[1]. Alvarez-Garrido, E. (2020). Uncovering the Impact of Venture Capital Firms on Startup Innovation. In Academy of Management Proceedings (Vol. 2020, No. 1, p. 21127). Briarcliff Manor, NY 10510: Academy of Management.

[2]. Shabanova, L., Ismagilova, G., Salimov, L., \& Akhmadeev, M. (2015). PEST-Analysis and SWOTAnalysis as the most important tools to strengthen the competitive advantages of commercial enterprises. Mediterranean Journal of Social Sciences, 6(3), 705.

[3]. Barnardo, C., Reyneke, M., Ferreira, C., \& Robertson, J. (2021). GrowBox: the reality of growth challenges for a social entrepreneur in Cape Town. Emerald Emerging Markets Case Studies.

[4]. Sammut-Bonnici, T., \& Galea, D. (2014). PEST analysis.

[5]. Carruthers, H. (2009). Using PEST analysis to improve business performance. In practice, 31(1), 37-39.

[6]. Koumparoulis, D. N. (2013). PEST Analysis: The case of E-shop. International Journal of Economy, Management and Social Sciences, 2(2), 31-36.
[7]. Chaney, S., \& Morath, E. (2020). April unemployment rate rose to a record $14.7 \%$. Wall Street Journal, May, 8.

[8]. Lukeš, M. Department of Managerial Psychology and Sociology, University of Economics, Czech Republic. Teaching Psychology of Entrepreneurship, 203.

[9]. Bagautdinova, N., Nayda, A., Hayrullin, B., \& Arzhantseva, N. (2014). Behaviour of Households on Financial Investments Market. Mediterranean Journal of Social Sciences, 5(12), 103-103.

[10]. Burżacka, M., \& Gąsiorowska, E. (2016, September). The importance of venture capital financing of startup companies. In Forum Scientiae Oeconomia (Vol. 4, No. 3, pp. 141-150). 